\title{
Early Childhood Education as a Site of Ecocentric Counter-Colonial Endeavour in Aotearoa New Zealand
}

\author{
JENNY RITCHIE \\ Te Whare Wānanga o Wairaka, Unitec Institute of Technology, Auckland, New Zealand
}

\begin{abstract}
This article draws upon a range of theoretical domains, first to outline the historical rationale for the urgent changes needed to challenge and transform the dominator culture which has justified exploitation of Indigenous peoples and the resources of the earth. It invites educators to reconsider the narratives that are either consciously or inadvertently promoted in our work, suggesting that we can learn from Indigenous epistemologies in which humans are situated alongside earth others, as respectful, related guardians and caretakers. It finally draws on some examples from a recent qualitative study conducted with ten early childhood centres from across Aotearoa, to illuminate possibilities for enactment of counter-colonial renarrativisation within early childhood settings in service of an ethical project of enhancing relationalities, reconnecting children and their families with the more-than-human world.
\end{abstract}

\section{Introduction}

Colonial systems have historically imposed their imperial patterns of dominance around the world: these modes of domination include dominance over women and Indigenous people, but also over the lands, waters, natural resources and creatures inhabiting these (hooks, 2003). Consequences have been horrific and widespread. Indigenous peoples have been disenfranchised to various extents, of their lands and languages. The future of humanity is now seriously threatened by multiple breaches of safe planetary boundaries (McIntosh, 2008; Hansen, 2009; Magdoff \& Foster, 2011; Stockholm Resilience Centre, 2012). A dramatic, even desperate, response is clearly called for. Educators can serve to generate awareness of the shifts that are required as to our ways of knowing, doing and being, as people in relation to each other, as well as in relation to the morethan-human world (Haraway, 2000). Early childhood educators deal on a daily basis with ongoing enactment of an ethic of care, an ethic which can be extended with ease to embrace caring for both living and non-living elements of our environment. In pre-technological societies, people needed to live closely with the earth, eternally mindful of weather and seasons, respectful of the intimate localised knowledges and skills required to maintain an abundance of resources. Many Indigenous cultures, such as the Indigenous Māori in Aotearoa, have retained traditional understandings pertaining to human relationality with our planet and all the living and non-living cohabitants, alongside whom we have evolved over millennia (Suzuki, 2011). For Māori, the Earth Mother Papatūanuku and the Sky Father Ranginui are the original ancestors not only of people but also of fellow descendants - the trees, animals, birds and insects. All living creatures are related through this genealogy. This is a form of relationality that differs from the binary dynamic of human dominance over nature, in that this view of relationality positions humans as cohabitants of a shared realm, reflecting an ethic of care and respect for the more-than-human world as something to which humans are privileged to be in relation with. 
This article will first outline the ideologies that have enabled the exploitation of both Indigenous peoples and the environment, and then challenge educators to develop a critical awareness of the impact of the narratives that we perpetuate. As educators we need to give careful consideration to the offerings sometimes made available through our efforts to build deep relationships with Indigenous peoples, of different ways of being, knowing and doing - an orientation which is profoundly respectful of our relationality within the cosmos (Martin, 2008). Finally, some examples of data gathered from early childhood centres in a recent study in Aotearoa [1] will be offered by way of illustrating some possibilities for enactment of interconnected relationalities demonstrating a sense of interconnectedness with the more-than-human world. These are reflective of Māori understandings, as mandated in the New Zealand national early childhood curriculum, Te Whāriki. He whāriki mātauranga mō ngā mokopuna o Aotearoa: Early childhood curriculum (Ministry of Education, 1996).

\section{Impacts of Colonisation and Globalised Technological Exploitation of the Planet}

The assumption of a right to exploit living and non-living others lies at the heart of historical and ongoing patterns of colonisation, exploitation of Indigenous people, habitat destruction, resource depletion, and pollution of earth, air and waters, the effects of which are now culminating in the current severe international climate crisis and in widespread species extinction. The pattern of settler/colonial domination of Indigenous peoples can be viewed as a mirroring of the domination and exploitation of non-humans (Rose, 2005). Moreover, the extent of destruction or protection of biodiversity in any particular location is closely linked to the well-being of cultural diversity in that same region (Curry, 2011).

A respected Māori theologian, the Reverend Māori Marsden, described the responses from his elders when, on his return from World War II, he had explained to them some of his wartime experiences. He relates the response of one of his elders to his description of the atomic bomb:

'Do you mean to tell me that the Pākehā scientists (tōhunga Pākehāa [2]) have managed to rend the fabric (kahu) of the universe?' I said 'Yes.' 'I suppose they shared their knowledge with the tūtūa (politicians)?' 'Yes.' 'But do they know how to sew (tuitui) it back together again?' 'No!' 'That's the trouble with sharing such 'tapu' [3] knowledge. Tūtūa will always abuse it.' (Marsden, 2003, p. xiii)

Marsden considers that the present capitalist, materialist, positivist system positions people as living in disharmony with the cosmic process, with this physical universe, and what is more pathetic, within [their] own ranks internationally, nationally, locally, culturally, socially, economically, politically, legally, philosophically, metaphysically, theologically and religiously' (Marsden, 2003, p. 52). For Marsden, an alternative construction is required, since '[o]nly a metaphysic that provides an integrative element across the whole spectrum of life, which produces a holistic approach to life, can unify its diverse elements and allow us to achieve a balance and harmony conducive to life abundant' (Marsden, 2003, p. 53).

In Aotearoa New Zealand, the history of colonisation by Britain meant that many laws were passed to divest Māori of their collectively owned lands to enable settlement and farming (Orange, 1987; Walker, 2004). Initially huge tracts of native bush were converted to pasture for sheep which provided wool and mutton for export. Historian James Belich has described the situation of the settlers supplying produce to the 'mother-country' Britain thus: 'By 1940 Australia and New Zealand were pumping 620,000 tons of meat a year into Britain's gaping maw' (Belich, 2009, p. 366). In 1985, there were 69,561,427 sheep in the 'New Zealand flock' (Wall, 1985, p. 242), while the human population sat at a mere $3,303,100$. More recently, dry stock farms have been converted to dairy farms. By 2010, the 4.4 million cows outnumbered the 4.39 million New Zealanders (NZPA, 2010). The unique native biodiversity of Aotearoa is in serious decline. Habitat loss has resulted from the conversion of whole ecosystems into farms, pine plantations and cities, with the consequential loss of $32 \%$ of endemic land and freshwater birds (New Zealand Biodiversity Information Online, 2011).

In a parallel process, the Māori population was decimated by introduced disease, dislocation and demoralisation, falling from pre-colonisation estimates of between 150,000 and 200,000 to a recorded low of 42,114 in 1896 (Jackson, 1931; Statistics New Zealand; Tatauranga Aotearoa, 2011). 
Meanwhile, in the 35 years between 1851 and 1886, the settler population increased 22-fold, from 26,000 to 580,000 (Belich, 2009). Until comparatively recently, Māori education had an assimilationist agenda that aimed to prepare Māori girls for domestic roles, and Māori boys for agricultural work (Simon, 2000). Deficit discourses prevail (Smith, 1999), notwithstanding current policy initiatives which attempt to transform these (Ministry of Education, 2008). This new policy direction offers a critical analysis to educators in all sectors regarding their potential role in perpetuating historical deficit discourses which have narrowed expectations, confining Māori to poor educational outcomes; instead, it challenges us to adopt a new discourse which values Māori as Māori, shifting the discourse of deficit to one of viewing 'being Māori' as an advantage (Ministry of Education, 2008).

During this era of colonisation, traditional knowledges and the histories and stories that contain them have been marginalised by colonial and then modernist western globalised culture, a monolith in which too often 'the felt primacy of place is forgotten, superseded by a new, abstract notion of "space" as a homogeneous and placeless void' (Abram, 1996, p. 184), where the land and people are positioned in service to 'the economy'. As Val Plumwood, the Australian eco-feminist theorist, explained: 'Hyperseparation and homogenization lead us to classify the land as pure nature or "wilderness", in ways that obscure its continuity with and dependency on culture, and erase the human stories interwoven with it, especially those of its indigenous people' (Plumwood, 2006, p. 141). Deborah Bird Rose, whose long association with Indigenous peoples in Australia has led to her current research focus on ecological and social justice responses to climate change, describes this un-storying of the world as a form of de-narrativisation, which positions the world as 'devoid of mind' (Rose, 2004, p. 183). This denarrativisation operates on two planes:

The first is social: as settler-descended people we inhabit country for which other people already have stories. This is not empty or unstoried land. The second is ecological ... the belief that the world is expressively inert does not destroy the world's expressivity. Modernity may damage our ability to hear ... [and this] refusal to hear stifles or destroys living things, thereby reducing the multivocal expressivity of the world. (Rose, 2004, p. 183)

Rose has invited us to consider an ethic of love in framing our urgent pedagogical response to such extinctions (Rose, 2011). So, in defining the parameters of a project of renarrativisation motivated from an ethic of love, we need to carefully consider the stories that, as teachers, we choose to promote. As Rose has written, 'Consciousness of connectedness entails choices made with courage and directed toward care' (Rose, 2011, p. 10).

\section{What (or Whose) Stories Do We Tell?}

We, as teachers, teacher educators, and scholars of education, are situated in a powerful position as shapers of narratives which will be taken up by young children and be transmitted forward into future generations. We are complicit in the shaping of future ethics, since '[i]t isn't that the history itself determines these narratives, but that the narratives shape the history' (Haraway, 2000, p. 128). As Donna Haraway, Distinguished Professor Emerita of the History of Consciousness Department at the University of California, Santa Cruz, has written, 'We exist in a sea of powerful stories' (Haraway, 1997, p. 45). The story that the western world currently promotes about our role on the earth 'is the story of culture transcending nature' (Rose, 2003, p. 64). It is an ethical imperative, and an intervention (perhaps more than modest), for early childhood educators to actively engage in changing this story (Haraway, 1997; Rose, 2004).

All cultural groups have narratives at the heart of their world view which are foundational in providing paradigms and guidance for ethics and relationality. The paradigm reflected in western creation stories is one of hierarchical dominance, as seen in the Genesis narrative, by humans (men) over the non-human world. This contrasts with the interdependence and cooperation seen in many Indigenous creation stories (King, 2005, p. 301). Those of us with settler ancestry might do well to consider the answer to the question 'If this is your land, where are your stories?' (Chamberlin, 2004, p. 1). The western project of globalised, technologised resource extraction, production and transfer to benefit 'the economy', resulting in a growing gap between rich and poor both within and between nations, relies on the unquestioned exploitation of low-paid workers, of 
the earth's resources, and of non-human beings, perpetuating narratives of exploitation and abuse of power. The eco-theologian Thomas Berry has suggested:

It's all a question of story. We are in trouble just now because we do not have a good story. We are in between stories. The old story, the account of how the world came to be and how we fit into it, is no longer effective ... We need a story that will heal, guide, and discipline us. (Berry, 1988, pp. 123-124)

As previously mentioned, we as educators face a profound ethical responsibility in choosing the stories, examining the discourses we perpetuate. We cannot hide behind the façade of evasion of this responsibility by claiming we determine our programme offerings purely in response to 'children's interests', providing an 'emergent curriculum' - common discourses in early childhood education centres in our country. Children will only be able to access the narratives, experiences and resources which we as a community afford them access to. Children are richly responsive to the landscape, the physical, tangible, sensory world in which they are situated (Blair, 2009). Educational programmes can work to afford children access to the particular Indigenous and local stories and histories which have been made available to the public domain by the Indigenous peoples of those places. And we can further recognise that it is the obligation and particular role of elders and teachers in Indigenous cultures to ensure the transmission of these stories, these specific local knowledges of the birds and trees, the seasonal cycles, and how to obtain and utilise the medicinal healing properties sourced from the bush. Further, through story as well as by active engagement in the outdoors, children can be facilitated in their sense of relatedness to the earth and the living and non-living world, and in their dispositions of relationality to their world. Stories can be taken up in various ways:

Stories are not so much about rules as they are about types of actions and responses; they demarcate relationships through recounting events. It is up to individuals to identify the choices and consequences, and relate them to their own living experiences. (Rose, 2000, p. 103)

Stories make sense in the extent to which they provoke and evoke responses by enlivening the senses, through which they may 'renew and rejuvenate one's felt awareness of the world' (Abram, 1996, p. 265).

\section{Listening to the Earth}

The positivist, scientific, cognitively centred paradigm of much western thought operates in denial of the intuitive understandings that many Indigenous people have traditionally maintained, as a responsibility of their sense of relatedness to the earth. It has been proposed that Indigenous knowledges and values of relationality with the earth offer a counter-paradigm to western scientific technicist exploitation and destruction of the earth: 'As complex as the question of indigeneity may be, we believe that the best interests of indigenous and nonindigenous people are served by the study of indigenous knowledges and epistemologies' (Kincheloe \& Steinberg, 2008, p.137).

The inherent 'intelligence' of our planet and the cosmos is reflected in the recursive flows of benefit, whereby life serves other life in complex ways, producing roles for humans that Indigenous people have traditionally fulfilled. Through her extensive work with a range of Australian Indigenous communities, Rose points out that these inter-connectivities are reciprocal. Ecosystems flourish 'through looped and tangled benefits. The underlying proposition is that the life of most living things is for others as well as for itself (Rose, 2005, p. 296).

\footnotetext{
The intelligence of the earth - which may simply be a pale reflection of the intelligence of the universe - is not something that mainstream scholars are ready to discuss. The insights we may gain from connecting to such a larger cognitive force - insights often appreciated by indigenous peoples more than Western scholars - can become one of the most important dimensions of emancipatory knowledge work of the future. (Kincheloe, 2008, p. 6)
}

Plumwood has called upon us to question a human-centric focus which inhibits our capacity to be open to recognition of the 'creativity of earth others' (Plumwood, 2006, p. 117). She considers that '[i]t is eminently rational, in our present circumstances, to follow critical methodologies 
foregrounding multiple agencies in the more-than-human world, both in our immediate lives and more generally in the universe' (Plumwood, 2006, p. 117).

Reconceptualising the compartmentalised nature of the scientific paradigm has begun to enable an awareness of the ability of cosmological intelligence to shift beyond the realms of theology into physics and other sciences. This involves recognition of the interrelationship and inter-dependence of life, the planet and the universe, which reflects its own form of 'intelligence'. The late Joe Kincheloe, a North American critical pedagogue, envisioned the challenge of developing 'a variety of sociopolitical, economic, ethical, aesthetic, cognitive, and educational ways to put these ideas into action' as being a key task to be faced by contemporary educationalists (Kincheloe, 2008, p.15). 'Here creativity and historically significant work become important in an ontology of becoming. In this living universe, the inner world of consciousness is never unconnected to the physical cosmos we see around us' (Kincheloe, 2008, p. 15).

Intrinsic to meeting this challenge to provide a radical, earth-protecting alternative to the rational scientific paradigm of knowledge production is a de-centring of humans as the locus and focus, generating instead a non-hierarchical view where humans are relocated to serve within a wide, complex, interconnected network, as opposed to seeing ourselves as the predominant actors on the world stage. North American peace education scholar Edward Brantmeier has suggested that ' $[\mathrm{s}]$ hifting from an anthropocentric to an ecocentric environmental ethic that would dismantle certain aspects of the dynamics of this dominance paradigm might enable planetary justice and human sustainability' (Brantmeier, 2010, p. 250). Furthermore, the shift required involves a move from dependence on rational cognition as a primary means of knowing, to a multi-sensory facility, founded in empathy for the 'Other', including non-human 'Others'. Kincheloe and Steinberg (2008) have proposed the notion of a 'multilogicality' which 'values the intimacy of an emotional connectedness that allows empathetic passion to draw knower and known together' (p. 139). This is something evident in the ontologies and epistemologies of Indigenous peoples:

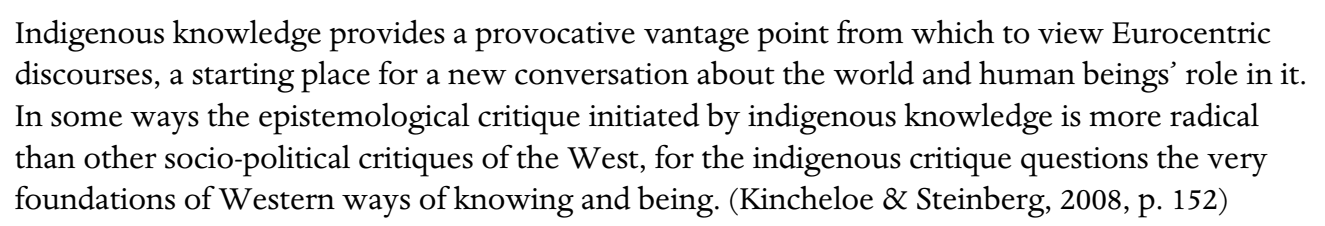

There has in recent decades been an increasing quantity of scholarship from an eclectic range of theoretical perspectives which includes not only Indigenous and anthropological perspectives, but also deep ecology, ecofeminism, and environmental philosophy. These accumulated perspectives 'demonstrate the history, the power and consequences of the epistemological error that asserts that humanity is fundamentally separate from, and can control, Nature' (Rose, 2004, pp. 188-189). Drawing upon local Indigenous perspectives to inform our theorising may enable us to transcend the artificial binary between humans and the non-human world and even that of epistemology and ontology, countering the socially constructed boundary between people and the more-than-human world (Haraway, 2000).

Whilst, potentially, people have the emotional, cognitive, ethical and political responsibility and response-ability to determine the fate of the planet, we also need to recognise that non-humans exercise their own powerful agencies in the world (Haraway, 2000). A Deleuzian-inspired understanding of agencies positions humans alongside all other 'bodies' in enactment of respective agency. In this reconceptualisation, " $[t]$ here are no "sovereign" individuals who act upon the world; there are only bodies that are produced through their contexts and connections with the world' (Hickey-Moody \& Malins, 2007, p. 4). This generates an ethical situation focused on maximising the capacities and potentials of all bodies, affirming differences, and 'opening up the potential for the unknown' (Hickey-Moody \& Malins, 2007, p. 4). This disruption of the taken-for-granted through a deliberate re-examination and expansion of our understanding of ethical relationality is a strategy aimed at disrupting the pervasive problematic legacy of colonial discourses of domination, and a move towards constructing post-colonial alternative ethics and ontologies (Bignall, 2007). 


\section{Pedagogical Stories of Relatedness as Life-serving Resilience: some narratives from a recent study}

We are increasingly facing impacts of widespread environmental degradation, such as extreme flooding and droughts; hunger and poor nutrition resulting from crop failures; pollution and climate change-related illnesses; and salt-water contamination of drinking-water supplies from rising sea levels deluging low-lying islands (Lawler, 2011). The response that is required here is an ethically situated project of recuperation aimed at restoring connection between humans and the non-human world (Rose, 2004). As Thomas King has pointed out, if we want to promote a different ethic, we need to tell a different story $(2005$, p. 164). The ethical project facing teachers is to generate narratives which 're-situate the human' (Rose, 2005, p. 302) as a fellow co-habitant and guardian of our planet. We can learn much from Indigenous understandings, such as a recognition that 'the life of most living things is for others as well as for itself (Rose, 2005, p. 296). Indigenous knowledges are intricately connected to specific locales and histories, and these understandings are related through stories, repositories of knowledge reflecting particularities of ecologies and place.

Intrinsic to the enactment of this shifted positioning is a disposition of listening to, of learning to hear, and of understanding the earth, being open and responsive to the non-human realm. This in turn will enable a respectful, non-hierarchical appreciation of the interconnected patterns of complexities and reciprocities, rhythms and cycles of the world, and a view of humans and nonhumans as co-participants 'in recursive and entangled bonds of mutual benefit' (Rose, 2005, p. 301). Local knowledges of care for self, others, and the environment can serve as the source of a renarrativisation undertaking which aims to reconfigure our [western] notions of being human, to a human being-ness which resides in 'kinship with nature' (Rose, 2005, p. 303), and which reframes humanity or becoming human as 'an interspecies collaborative project' (Rose, 2011, p. 11).

In 2008-2009 a group of around 25 teachers from ten different early childhood care and education centres throughout Aotearoa New Zealand came together with four research codirectors to work on a project which focused on 'caring for ourselves, others and the environment in early years education' (Ritchie et al, 2010). The collaborative project was informed by kaupapa Māori (Māori philosophy) and narrative research methodologies (Hollingsworth \& Dybdahl, 2007; Otterstad, 2007; Cannella \& Manuelito, 2008; Jones \& Jenkins, 2008; Ritchie \& Rau, 2012). An initial day-long hui (gathering/meeting) of co-directors and teachers generated and explored shared understandings of the research questions and ethical expectations and processes. There were four key areas of focus. We were interested in exploring the philosophies and policies guiding teachers/whannau (families) in their efforts to integrate issues of ecological sustainability into their current practices; ways in which Māori ecological principles were informing and enhancing a kaupapa (philosophy) of ecological sustainability, as articulated by teachers, tamariki (children) and whānau; how teachers/whānau articulated and worked with pedagogies that emphasise the interrelationships between an ethic of care for self, for others and for the environment in local contexts; and how the centres worked with their local community in the process of producing ecologically sustainable practices.

Data were gathered mainly by teachers who were active co-researchers in this project, and also by co-directors during their visits over the period of one year, and included photographs, documentation of tamariki and whannau (children and family) narratives, audio recordings of discussions, video footage of centre activities, audio and video recordings of co-theorising sessions, and so forth. Data analysis and theorising processes involved dialogical negotiation of coconstructed understandings (Siraj-Blatchford \& Siraj-Blatchford, 1997) and collaborative storying (Bishop, 1996, 1997) whereby findings from different early childhood settings were shared and discussed during visits by the research directors. These discussions were often noted or recorded, and this formed another layer of data. A final collective day-long hui was the opportunity for all the teaching teams to share their key findings with the entire group, which included the Māori elders who had guided and supported our processes. The presentations and intervening discussions from this hui formed yet another tier of data and shared theorising. The following section draws upon some examples from the study which illustrate ways in which Indigenous perspectives invoking respectful relatedness with the earth and its cycles were employed within early childhood education contexts. 


\title{
Caring for Papatūanuku and Ranginui - our Earth Mother and Sky Father
}

The teachers of Hawera Kindergarten, in a small North Island rural township, decided to frame their approach to their research involvement within a Māori world view of the seasonal cycles (Knudtson \& Suzuki, 1992; Davis, 2009). This kindergarten has three teachers, two of whom are Māori. The teachers discussed with the children and their families understandings gleaned from the guidance of the traditional Māori maramataka (a calendar which indicates auspicious times of the month for planting particular crops and when particular fish are most likely to be caught) as to customary Māori practices at each particular point in the year, juxtaposing these alongside what was going on within their own kindergarten programme at the same cyclical point. For example, at the outset of the study they undertook some research which enabled them to share with children and families how, traditionally, Pipiri (June) was the time of year when:

\begin{abstract}
All things of the earth are contracted owing to the cold, as also are the people. For [traditional]
Māori this meant: Bird snaring and rat trapping; All game was preserved; Moki, Warehou [two species of fish] and kakahi mussels were collected; Breaking up new ground for planting of crops began; Fungi was collected for medicinal purposes.
\end{abstract}

They then related that, during this same season, 'for us this means' a range of activities, including gardening, noticing seasonal indicators such as spring shoots of daffodils appearing on the surface of the bare ground, the recycling of food scraps to feed local pigs, and soup-making. The following is an excerpt from centre pedagogical documentation gathered by the teachers:

23/6/08. At mat-time I talked to the children about gardening and growing plants. I asked 'Shall we grow veggies for the rabbit or veggies to share with all the children and their whänau [families]?' The children decided that sharing the veggies was what we should do. I told them I would need their help someday soon to get the gardens ready - weeding etc. I also explained that we were going use the Māori gardening calendar to help us with our gardening work. We made a list of veggies we might like to grow.

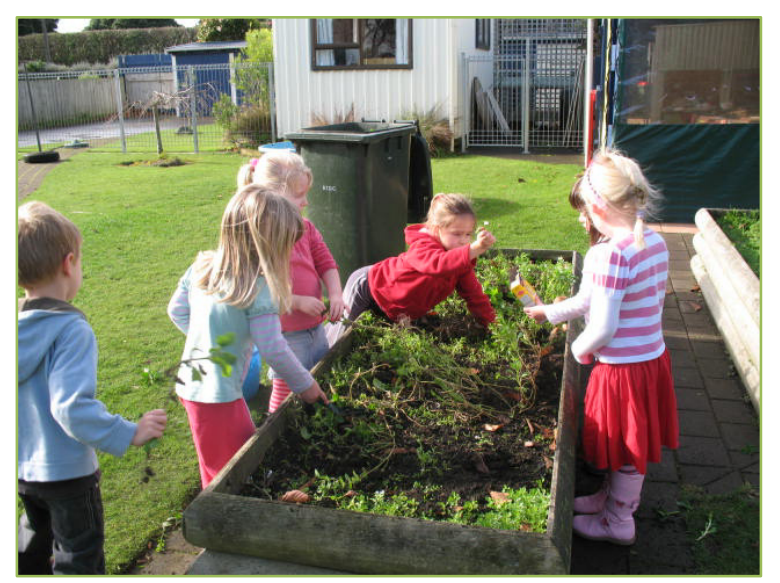

Figure 1. Children weed the raised vegetables gardens at Hawera Kindergarten. Photo used with permission.

25/6/08 Mary [4] and her Mum bought in an egg-tray, seeds (carrot, broad beans and peas) and a bag of seed-raising mix. Mary explained really well what we needed to do. Later in the morning several children helped to plants the seeds in the egg trays. Now we have to take care of them and wait!

$25 / 6 / 08$. The children and Judith (teacher) got outdoors between rain showers and began weeding the raised garden beds. We talked about getting the gardens ready for planting, and about putting good things back into the soil so our plants will grow well. (Hawera Kindergarten) 
In July 2008, the Hawera Kindergarten teachers chose to focus on traditional Māori rongoa (traditional Māori medicines) which are drawn from the healing properties of native plants, again doing their research to locate relevant local resources, such as a book containing a collection of narratives of local Māori healers (Tito et al, 2007), and reference books on native plants. The teachers recorded:
We are learning about sustainability through traditional Maori practices. We are including a focus on rongoa and how important Papatuanuku [Mother Earth] is in the Māori world. To support this, we have been reading a story book called 'Koro's Medicine' (Drewery, 2004) with the children. It tells of a boy's holiday with his Koro [Grandfather] and how Koro passes the knowledge of rongoa down to his mokopuna [grandchild].

This children's story was read extensively, and teachers also brought in books about native plants and their medicinal properties to enable children to identify the ones that were growing outside around the kindergarten. This is an example of renarrativisation which honours the traditional role of specialist elders in transmitting particular knowledges pertaining to the way in which the natural world holds and shares the knowledge of healing, restorative, life-enhancing powers. Human resilience is dependent on the 'connectivity and commitment' of our relationship with our planet (Rose, 2004, p. 49). 'It acknowledges the force, or desire, of living things to flourish, to be in connection, to find their mutually beneficial patterns, and to restore to the world the power of life which is always in a delicate relationship with death' (Rose, 2004, p. 49).

At Richard Hudson Kindergarten, in the South Island city of Dunedin, the teachers elicited the support of a local elder, Huata Holmes, who shared local Southern Māori cosmologies, that is creation stories, with the children. It was evident from their art-work and stories that this had great resonance for these children. The children shared their understanding about the need to care for the Earth Mother, Papatuanuku, and the Sky Father, Ranginui. As an example, the teachers offered the following summary of a discussion with a parent regarding her daughter's understandings:

Tina's daughter, Penny, is four years, 10 months old and attends our morning sessions at kindergarten. Penny, always a thinker, has really embraced the research focus and she can articulate her understandings of Ranginui/Rakinui [5] and Papatuanuku very clearly. She believes that Papa [6] is a living being/person and that she has feelings. Tina sees Penny's concern about Papa being covered in junk. Penny gets upset when she sees smoke going up into the air, as she feels that it is not good for Rangi's lungs. Penny's real concern is all the rubbish and she has wholly embraced the litter-less lunchbox goal. Tina had made filled rolls for the children's lunches one day and was unable to find a reusable container to fit. She used 'sad-wrap' [7] instead. When Penny saw what her Mum had done, she was not happy and communicated a 'why do it?' message. Tina thinks Penny's concern about rubbish is a good thing to be worried about. If there is time in the morning, Penny likes to take a bag on her walk to kindergarten and pick up rubbish. She does it out of a genuine concern about the environment. Tina stressed that Penny does not do it for attention or praise; she does it because she thinks it is the right thing to do. (Richard Hudson Kindergarten)

Adele, one of the teachers at this kindergarten, became concerned when she heard that the children were very tempted to pick the blossoms of a flowering plant. She then researched and shared with the children the Māori construct of rāhui, a prohibition placed on a resource as a strategy of kaitiakitanga (guardianship; caring for the land). Adele explained:

Through reading widely for this research, I have deepened my understandings about conservation from a Māori perspective. I feel that my understandings are becoming layered now as I add more knowledge to what I already know. It was while trawling through the Te Ara/New Zealand Encyclopedia site [Ministry of Culture and Heritage, 2005-2009] that I saw the heading 'Conservation Through Rāhui'. It interested me, and 'planted a seed of thought' in my mind. It talked about limits being placed on resources when they were scarce to ensure their continuation in the long term. It explained that the limits were localised, and entirely respected and adhered to. When I heard the other teachers talking about the flowers from the front steps being picked, the idea in my head began to germinate. We had a parallel situation here at kindergarten - a localised shortage on a precious resource. I could teach the children about conservation through rāhui. This Māori conservation concept would be hard for children to understand without a 
practical application, or a real context. This was the perfect opportunity to teach it meaningfully, to plant a seed of understanding in their minds, as they develop their bicultural understandings of the necessity for such concepts. The flowers on the front steps had a rāhui placed on them to ensure they lasted, and flowers for the enjoyment and creativity of the children were sourced elsewhere. And it worked! (Richard Hudson Kindergarten)

During discussion between Adele and two of the co-directors of our study, one of whom is Māori, it became clear that Adele, in determining her course of action, had been very mindful of the potential for Pākehā appropriation of Māori constructs. After doing her research, which included consulting a government webpage intended to inform the general public of about Māori conservation practices, she had been careful to check her intentions with a Māori consultant, in order to ensure that the introduction of the notion of rāhui would be appropriate in the kindergarten context. Through Adele's thoughtful, intentional process, children were introduced to, and came to respect and follow, an Indigenous conservation strategy. This is an example of counter-colonial enactment whereby tikanga Māori (practices which are correct for Māori) become 'normal' everyday practice within the kindergarten setting (Smith, 1999).

At a culturally diverse urban kindergarten in the North Island city of Hamilton, teachers Pat and Pera have a very strong commitment to implementing kaupapa Māori values. They describe their programme as 'operating under the cloak of whanaungatanga (including families) which embraces: whakapiripiri mai - coming together; manaakitanga - caring and sharing, making people feel at ease; and rangimarie - peace' (Ritchie et al, 2010, p. 73). As part of their annual programme, Pat and Pera have for many years conducted a range of experiences relating to kaupapa Māori, which has included a trip to a local area of native bush. In the year of the research project, this particular location was unavailable. Pat described how she and her Māori colleague Pera had carefully explored new possible locations for that year's excursion into the native bush, finally locating a site at Pirongia Forest Park, just outside the city:

Pera and I went just to check out to see what was there, so we [would have] a safe place where we can take our children. Where parents with prams can come, and not feel like it's a hassle; we want them to enjoy the experience. And so it's a picnic on Pirongia [a local mountain]. You park the bus, you walk through from here to just the other side of the fence there, so it's this wide smooth path, but the trees are ancient. I've never seen such huge tree ferns, massive, and trunks on them, massive and lots of tawa [an indigenous tree]. There's a little glade ... and there's this like a doorway in the thick bush ... and you walk in and it's an area about the size of this carpet maybe, with trees all around ... It's like a room in the bush. So we want to take the children to that, because this is like being in a bush, without it being too scary, and so if it gets overwhelming - because it can - you just go through that doorway and you're right outside again - turn around - back in you come. And I wanted them to get that feeling of: 'It's okay in the bush' ... And along the path it's really the ancient trees that you see; and when we walked there, there were tawa trees with these big fat purple berries that had fallen on the ground and so there should be kereru [indigenous wood pigeons] ... So we talked [with the children] about tui [another indigenous bird] and the red fantails and yes, the kereru, and the $r \bar{u} r \bar{u}$ [indigenous owl]. So those are the things we'll do. When we come back, we'll just start talking, because our trips involve projects, and so this is just the beginning of what could be projects. (Bellmont Kindergarten Te Kupenga)

Pat and Pera were very mindful in choosing a location for the children that would be nonthreatening, safe and welcoming. They then concentrated on preparing the children to enable them to be receptive to the richness of their forthcoming bush experience, alerting them to the particular native species of birds and trees that they were likely encounter. Pat said, 'We want them to just think about being in the bush.' These teachers are carefully planning and providing learning opportunities that enact their espoused philosophy of whanaungatanga (including families); whakapiripiri mai (coming together); manaakitanga (caring and sharing, making people feel at ease); and rangimarie (peace). In offering the children and families of their multicultural centre this safe, peaceful encounter with the native bush, they are enabling their visiting party to share what they described as a spiritual experience of closeness not only with one another, but also with all those 
who dwell within the realm of Tane Māhuta, the spiritual guardian of the forests, trees, birds and insects.

\section{Concluding Thoughts}

Michael Bonnett has positioned 'alienation from nature and from self as being 'highly interrelated and key to our ability to knowingly despoil the environment' (Bonnett, 2006, p. 271). An awareness of our interdependence with nature is central to a project of re-weaving the torn fabric of life. This returns us to the notion of an ethic of love, of care, and of relationality between self and more-thanhuman others as being fundamental to the project of counter-colonial renarrativisation which moves beyond anthropocentric planetary devastation (Rose, 2011). Mosquin and Rowe believe that '[a] courageous change in attitudes and activities is urgent' $(2004$, p. 3). They consider that the pathway required is a 'new worldview anchored in the planetary Ecosphere'. In recognising that '[b]eing is relation' (Simendon, 2005, as cited in Venn, 2010, p. 135), Venn (2010) has also called for 'a new problematic of life' which invites us to reconceptualise our understanding of

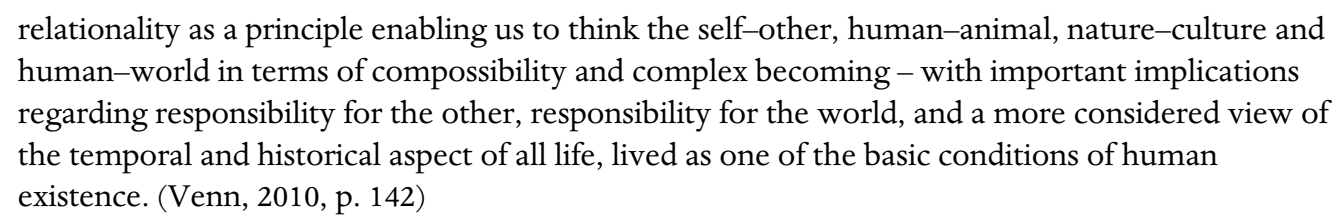

However, the required life-serving world view is not actually 'new', since it is one that is inherent to Indigenous ways of knowing, being and doing (Martin, 2008). Through reconfiguring our ways of being in relation with local Indigenous elders, narratives, and knowledges, early childhood educators can make available to young children pedagogies of hope grounded in relationality and an ethic of love which embraces the natural world and both human and more-than-human beings. The examples of early childhood care and education practice described in this article demonstrate the potential for early childhood education settings to be sites of intentional pedagogical countercolonial renarrativisation. This requires of teachers a commitment to both ethical responsiveness as well as preparedness to do the work required to develop relationships with the Indigenous people of their locale. This disposition of respectful responsiveness may allow teachers to be guided by Indigenous consultants in obtaining and applying relevant resources and providing opportunities for outdoor and wilderness experiences that deepen and extend the ways in which young children are enabled to access understandings of, and to enact, interrelatedness and connectedness not only with people from different backgrounds, but also with the land, waters and more-than-human cohabitants of our planet.

\section{Notes}

[1] Aotearoa is a Māori name for New Zealand.

[2] Tōhunga are experts; Pākehā are people of European ancestry.

[3] Tapu is sacred, esoteric.

[4] Pseudonyms have replaced real names; permission has been granted for use of photos.

[5] Rakinui is the Southern dialect for Ranginui, the Sky Father.

[6] Papa is an abbreviation of Papatuanuku, the Earth Mother.

[7] The children in this centre coined the term 'sad-wrap' to describe plastic food wrap, often known by a brand name of 'Glad Wrap'.

\section{References}

Abram, D. (1996) The Spell of the Sensuous: perception and language in a more-than-human world. New York: Vintage Books.

Belich, J. (2009) Replenishing the Earth: the settler revolution and the rise of the Anglo-world, 1783-1939. Oxford: Oxford University Press. 
Berry, T. (1988) The Dream of the Earth. San Francisco: Sierra Club Books.

Bignall, S. (2007) Indigenous Peoples and a Deleuzian Theory of Practice, in A. Hickey-Moody \& P. Malins (Eds) Deleuzian Encounters: studies in contemporary social issues. Basingstoke: Palgrave Macmillan.

Bishop, R. (1996) Collaborative Research Stories: Whakawhanaungatanga. Palmerston North: Dunmore.

Bishop, R. (1997) Interviewing as Collaborative Storying, Education Research and Perspectives, 24(1), 28-47.

Blair, D. (2009) The Child in the Garden: an evaluative review of the benefits of school gardening, Journal of Environmental Education, 40(2), 15-38. http:/ / dx.doi.org/10.3200/JOEE.40.2.15-38

Bonnett, M. (2006) Education for Sustainability as a Frame of Mind, Environmental Education Research, 12(3-4), 265-276. http:/ / dx.doi.org/10.1080/13504620600942683

Brantmeier, E.J. (2010) 'Self Re-education for Teachers: Gandhi, deep ecology, and multicultural peace education, in E.J. Brantmeier, J. Lin \& J.P. Miller (Eds) Spirituality, Religion and Peace Education. Charlotte, NC: Information Age.

Cannella, G.S. \& Manuelito, K.D. (2008) Feminisms from Unthought Locations: indigenous worldviews, marginalized feminisms, and revisioning an anticolonial social science, in N.K. Denzin, Y.S. Lincoln \& L.T. Smith (Eds) Handbook of Critical and Indigenous Methodologies. Los Angeles: Sage.

Chamberlin, J.E. (2004) If This Is Your Land, Where Are Your Stories? Toronto: Vintage.

Curry, P. (2011) Ecological Ethics: an introduction. Cambridge: Polity Press.

Davis, W. (2009) The Wayfinders: why ancient wisdom matters in the modern world. Toronto: House of Anansi Press.

Drewery, M. (2004) Koro's Medicine. Wellington: Huia.

Hansen, J. (2009) Storms of My Grandchildren: the truth about the coming climate catastrophe and our last change to save humanity. London: Bloomsbury.

Haraway, D.J. (1997) Modest_Witness@Second_Millennium.FemaleMan@__Meets_OncoMouse $\mathrm{T}^{\mathrm{TM}}$ :feminism and technoscience. New York: Routledge.

Haraway, D.J. (2000) How Like A Leaf: an interview with Thyrza Nichols Goodeve. New York: Routledge.

Hickey-Moody, A. \& Malins, P. (2007) Introduction: Gilles Deleuze and four movements in social thought, in A. Hickey-Moody \& P. Malins (Eds) Deleuzian Encounters: studies in contemporary social issues. Basingstoke: Palgrave Macmillan.

Hollingsworth, S. \& Dybdahl, M. (2007) The Critical Role of Conversation in Narrative Inquiry, in D.J. Clandinin (Ed.) Handbook of Narrative Inquiry: mapping a methodology. Thousand Oaks, CA: Sage. http: / / dx.doi.org/10.4135/9781452226552.n6

hooks, b. (2003) Teaching Community: a pedagogy of hope. New York: Routledge.

Jackson, P.G. (1931) Maori and Education. Wellington: Fergus \& Osborn.

Jones, A. \& Jenkins, K. (2008) Rethinking Collaboration: working the indigene-colonizer hyphen, in N.K. Denzin, Y.S. Lincoln \& L.T. Smith (Eds) Handbook of Critical and Indigenous Methodologies. Thousand Oaks, CA: Sage.

Kincheloe, J.L. (2008) Critical Pedagogy and the Knowledge Wars of the Twenty-first Century, International Journal of Critical Pedagogy, 1(1), 1-22.

Kincheloe, J.L. \& Steinberg, S.L. (2008) Indigenous Knowledges in Education: complexities, dangers, and profound benefits, in N.K. Denzin, Y.S. Lincoln \& L.T. Smith (Eds) Handbook of Critical and Indigenous Methodologies. Los Angeles: Sage.

King, T. (2005) The Truth about Stories: a native narrative. Minneapolis: University of Minnesota Press.

Knudtson, P. \& Suzuki, D. (1992) Wisdom of the Elders. Sydney: Allen \& Unwin.

Lawler, J. (2011) Children and Climate Change: children's vulnerability to climate change and disaster impacts in East Asia and the Pacific. Bangkok: UNICEF East Asia and Pacific Regional Office.

Magdoff, F. \& Foster, J.B. (2011) What Every Environmentalist Needs To Know about Capitalism: a citizen's guide to capitalism and the environment. New York: Monthly Review Press.

Marsden, M. (2003) The Woven Universe: selected writings of Rev. Māori Marsden, ed. T.A.C. Royal. Wellington: The Estate of Māori Marsden.

Martin, K. (2008) Please Knock before You Enter: Aboriginal regulation of Outsiders and the implications for researchers. Teneriffe, Queensland: Post Pressed.

McIntosh, A. (2008) Hell and High Water: climate change, hope and the human condition. Edinburgh: Birlinn.

Ministry of Culture and Heritage (2005-2009) Te Ara: the encyclopedia of New Zealand. Wellington: Ministry of Culture and Heritage. http:/ / www.teara.govt.nz 
Ministry of Education (1996) Te Whāriki. He whāriki mātauranga mō ngā mokopuna o Aotearoa: early childhood curriculum. Wellington: Learning Media.

Ministry of Education (2008) Ka Hikitia. Managing for Success: Māori education strategy 2008-2012. Wellington: Ministry of Education.

Mosquin, T. \& Rowe, S. (2004) A Manifesto for Earth, Biodiversity, 1(4), 3-9. http: / / dx.doi.org/10.1080/14888386.2004.9712713

New Zealand Biodiversity Information Online (2011) Our Chance To Turn The Tide: Whakakōhukihukitia te tai roruku ki te tai oranga. Wellington: Department of Conservation, Ministry of Fisheries, Ministry for the Environment, Ministry of Agriculture and Forestry. http: / / www.biodiversity.govt.nz/picture/biodiversity/state/index.html

New Zealand Press Association (2010) More Cows Than Humans, New Zealand Herald, 6 December. http: / / www.nzherald.co.nz/news/print.cfm?objectid $=10692521$

Orange, C. (1987) The Treaty of Waitangi. Wellington: Allen \& Unwin/Port Nicholson Press.

Otterstad, A.M. (2007) Doing and Unpacking De/colonising Methodologies: who is at risk? Contemporary Issues in Early Childhood, 8(2), 170-174. http: / / dx.doi.org/10.2304/ciec.2007.8.2.170

Plumwood, V. (2006) The Concept of a Cultural Landscape: nature, culture and agency in the land, Ethics and the Environment, 11(2), 115-150. http:/ / dx.doi.org/10.2979/ETE.2006.11.2.115

Ritchie, J., Duhn, I., Rau, C. \& Craw, J. (2010) Titiro Whakamuri, Hoki Whakamua. We Are the Future, the Present and the Past: caring for self, others and the environment in early years' teaching and learning. Final report for the Teaching and Learning Research Initiative. Wellington: Teaching and Learning Research Initiative/New Zealand Centre for Educational Research.

Ritchie, J. \& Rau, C. (2012) Exploring Possibilities for Critical Relational De/colonising Methodologies in Early Childhood Education Contexts in Aotearoa, in G.S. Cannella \& S.R. Steinberg (Eds) Critical Qualitative Research (CQR) Reader. New York: Peter Lang.

Rose, D. (2005) An Indigenous Philosophical Ecology: situating the human, Australian Journal of Anthropology, 16(3), 294-305. http:/ / dx.doi.org/10.1111/j.1835-9310.2005.tb00312.x

Rose, D.B. (2000) Dingo Makes Us Human: life and land in an Australian Aboriginal culture. Cambridge: Cambridge University Press.

Rose, D.B. (2003) Decolonizing the Discourse of Environmental Knowledge in Settler Societies, in G. Hawkins \& S. Muecke (Eds) Culture and Waste: the creation and destruction of value. Lanham, MD: Rowman \& Littlefield.

Rose, D.B. (2004) Reports from a Wild Country: ethics for decolonisation. Sydney: University of New South Wales Press.

Rose, D.B. (2011) Wild Dog Dreaming: love and extinction. Charlottesville: University of Virginia Press.

Simon, J. (2000) Education Policy Change: historical perspectives, in J. Marshall, E. Coxon, K. Jenkins \& A. Jones (Eds) Politics, Policy, Pedagogy: education in Aotearoa/New Zealand. Palmerston North: Dunmore.

Siraj-Blatchford, I. \& Siraj-Blatchford, J. (1997) Reflexivity, Social Justice and Educational Research, Cambridge Journal of Education, 27(2), 235-248. http: / / dx.doi.org/10.1080/0305764970270207

Smith, L.T. (1999) Decolonizing Methodologies: research and indigenous peoples. London and Dunedin: Zed Books and University of Otago Press.

Statistics New Zealand; Tatauranga Aotearoa (2011) Wellington: Statistics New Zealand. Tatauranga Aotearoa. http: / /www.stats.govt.nz/

Stockholm Resilience Centre (2012) Tipping Towards the Unknown. Stockholm: Stockholm University. http:/ / www.stockholmresilience.org/planetary-boundaries

Suzuki, D. (2011) The Legacy: an elder's vision for our sustainable future. Vancouver. Greystone Books/David Suzuki Foundation.

Tito, J., Pihama, L., Reinfeld, M. \& Singer, N. (Eds) (2007) Matarakau. Ngā kōrero mō ngā rongoā o Taranaki. Healing stories of Taranaki. Taranaki: Karangaora.

Venn, C. (2010) Individuation, Relationality, Affect: rethinking the human in relation to the living, Body Society, 16(1), 129-161. http: / dx.doi.org/10.1177/1357034X09354770

Walker, R. (2004) Ka Whawhai Tonu Matou. Struggle without End, rev. edn. Auckland: Penguin.

Wall, G.L. (1985) Flock Size Structure of the New Zealand Sheep Flock, New Zealand Journal of Experimental Agriculture, 13(3), 241-245. http:/ / dx.doi.org/10.1080/03015521.1985.10426089 
JENNY RITCHIE has a background as a child-care educator, kindergarten teacher, and kōhanga reo whānau member, along with 22 years' experience in early childhood teacher education. Her teaching, research and writing has focused on supporting early childhood educators and teacher educators to enhance their praxis in terms of enacting an awareness of cultural, environmental and social justice issues. Correspondence: jritchie@unitec.ac.nz 